\title{
Fugiendo vincimus! Isä, poika ja pyhä valta
}

\author{
SAATESANAT
}

Lähikuva-lehden varhainen mediakasvatus-numero ilmestyi vuonna 1992. Tuota ajankohtaa edeltänyt vuosikymmen oli monien sellaisten murrosten aikaa, jotka vaikuttivat suuresti myös mediakasvatuksesta käytyyn keskusteluun. Teknisistä uudistuksista kenties keskeisin väline oli videonauhuri. Sen myötä elokuva- ja televisiokasvatus (jota Suomessa edisti Elokuva- ja televisiokasvatuksen keskus ja sen julkaisemat Sinä-Minä-Me ja sittemmin Peili -nimiset lehdet) alkoi entistä enemmän muuttua puheeksi mediakasvatuksesta. Yksi esimerkki tästä muutoksesta oli Len Mastermanin teoksen Medioita oppimassa - mediakasvatuksen perusteet saattaminen suomeksi vuonna 1989. Keskustelupuheenvuoroja, virallisia mietintöjä ja oppimateriaaleja alkoi ilmestyä aiempaa tiheämmin. Mediakasvatuksen perusteita alettiin käsitellä monipuolisemmin, ja juuri tähän kenttään omalta osaltaan osallistui myös tuolloinen Lähikuvan numero.

"Fugiendo vincimus!"-tekstin ohella kirjoitin samaiseen teemanumeroon eräänlaisen johdannon otsikolla "Media, pelko ja politiikka". Se puolestaan rakentui pitkälti Gilles Deleuzen tuolloin tuoreeseen artikkeliin kontrolliyhteiskunnasta. Aiheen kytkeminen median ja kasvatuksen teemoihin saattoi vaikuttaa kaukaa haetulta, mutta kehityssuunnat sittemmin ovat kyllä tuoneet niitä lähelle, käsin kosketeltaviksi ja koettaviksi. Esimerkiksi yrityseetoksen kaikkivoipaisuus, josta Deleuze kirjoittaa, ulottuu sulavasti jo korkeakoulutukseen asti.

Steven Spielbergin elokuvassa Auringon valtakunta (Empire of the Sun, USA 1987) tuntuivat kiteytyvän yhden teoksen puitteissa monet niistä teemoista, joista mediakasvatuksen periaatteita käsittelevässä keskustelussa olin ollut kiinnostunut: lapsikuvaukset, kasvatukseen liittyvät tavoitteet, sodan kaltaisen poikkeustilan muodostama aatteellinen ympäristö, valtarakenteiden audiovisuaaliset ilmentymät ja niin edelleen. Kenties vielä näitäkin enemmän henkilökohtaiseen kiinnostukseen vaikutti se, että elokuva pohjautui nimenomaan J. G. Ballardin samannimiseen, omaelämäkerralliseen romaaniin. Ballard nimittäin oli noihin aikoihin lähes ainoa kirjailija, jonka tuotantoa - erityisesti aiempaa, tieteisfiktioksi luettua lyhytproosaa - olin seurannut jo vuosia melko systemaattisesti. Tähän nähden onkin kenties outoa, etenkin kun luen omaa tekstiäni tänään noin 25 vuotta myöhemmin, ettei artikkelissani juurikaan tutkita Ballardin romaanin ja Spielbergin elokuvan välistä suhdetta. Toisaalta, ja puolustukseksi voisin todeta, tämä suhde onkin oikeastaan enemmän adaptaation kuin mediakasvatuksen kysymys - ja sellaisena oman, erityisen tarkastelun ansaitseva.

Artikkelista kehittyi sittemmin seuraavan monografiani Aineeton syli (1996) alkulukujen aineisto. Samassa yhteydessä mediakasvatuksen kysymykset tarkentuivat omassa mielessäni nimenomaan mediatajua koskeviksi. Tässä koosteessa artikkeli paitsi kasvoi hieman laajemmaksi myös muodostui osaksi sarjaa, jossa Spielbergin muukin tuotanto näyttäytyi osana postmodernin elokuvan kokonaisilmettä. Artikkelin kantoaaltojen vaikutus näkyy vielä reilut kymmenen vuotta myöhemmin kirjassani Mediatajun paluu (2004) ja siinä tarkastellussa keskenkasvuisen teemassa.

Turussa, elokuussa 2018

Jukka Sihvonen 


\section{Jukka Sihvonen}

\section{FUGIENDO VINCIMUS! - Isä, poika ja pyhä valta}

\section{Kieltää ja kasvattaa}

Audiovisuaaliseen viestintäkulttuuriin kohdistuvan kasvatuksen tarpeellisuutta on totuttu perustelemaan lähinnä kahdella tavalla: a) koska lapset viettävät niin paljon aikaa eri medioiden parissa ja b) koska (jo edellisestäkin johtuen) medioilla täytyy olla suuri vaikutus vastaanottajiinsa. Ajan ja vaikutuksen kysymykset liittävät mediakasvatuksen läheisesti (ja jo varhaisessa vaiheessa) myös sensuuriin. Tässä suhteessa perustehtävänä on ollut yksinkertaisesti sen ajan rajoittaminen, joka lapsilla on ollut käytettävissään seurusteluun eri medioiden parissa.

Suomessa elokuvasensuuri syntyi vastaavista tarpeista jo varsin varhain:

Toukokuussa [1917] vanha kiistakysymys elokuvien säädyttömyydestä ja kohtalokkaasta vaikutuksesta nuorisoomme purkautui yllättävän kiihkeäksi keskusteluksi. Asialla oli toisistaan riippumatta kolme kasvavan polven intomielistä varjelijaa: Julia Stadius, Henrik Ståhl ja J. H. Tunkelo (18731948). Rouva Stadius ilmoitti, ettei hän koskaan käynyt elokuvissa. Tietonsa hän oli hankkinut naispoliiseilta. Eritoten esikaupunkien pienissä salongeissa lapsukaiset istuivat tuntitolkulla huonossa ilmassa. He tulivat useimmiten yksin ja viipyivät myöhäiseen iltaan myötäeläen jännittävät tapahtumat innosta tutisten. Tämän turmeltumisen sallittiin jatkua, vaikka tarttuviin tauteihin puututtiin ehkäisevin toi- menpitein. Ohjelmistoa tuli siistiä ja keskittyä opettaviin elokuviin.

Herra Ståhl haki vertauskuvansa väkijuomista: niistä maksettiin runsaasti veroa - elokuvat sisälsivät eettiseltä kannalta vielä kohtalokkaampaa myrkkyä, joten niitäkin tulisi raskaasti verottaa sivistävien pyrkimysten hyväksi. Tunkelo edusti kristillisiä piirejä, ja hän julkaisi mielipiteensä kahdeksansivuisessa vihkosessa "Elävien kuvien tarkastus Suomessa”. Julistusta jaettiin paheksuvin rintaäänin: “'Kuvissa käynti' on tullut intohimoksi, kuten väkijuomiin mieltyneille kapakkakäynnit; himon tyydyttämiseksi turvaudutaan valheeseen, petokseen, näpistelyyn, keinotteluun m.m." Elokuvien katsottiin myötävaikuttaneen rikollisuuden lisääntymiseen ja koululaitoksen opetustehtävän epäonnistumiseen. Suurissa kaupungeissa opettajat olivat poliisin rinnalla osallistuneet elokuvatarkastukseen ja yhteistyöstä oli hyviä kokemuksia. Tekijä esitti itsenäisen elokuvatarkastamon perustamista. Se hyväksyisi keskitetysti kaikki maassa esitettävät elokuvat. Lisäksi kunnille tuli antaa itsemääräämisoikeudet hyväksyttyihin elokuviin nähden. ${ }^{1}$

Elokuvaan kohdistuvien kasvatuksellisten pyrkimysten riippuvuus yhteiskunnallisesta yhteydestään käy hyvin ilmi, kun verrataan Suomen tilannetta 1920-luvun Neuvostoliittoon. Kuten tunnettua elokuvalle suotiin nuoressa kommunistivaltiossa varsin vahva poliittinen merkitys. Muun harrastustoiminnan ohella elokuvaesitykset tarjosivat työläiskerhoissa sekä opetusta että viihdettä. Ennen kaikkea elokuvaesityksillä oli kui- 
tenkin sosiaalista kanssakäymistä ruokkiva tehtävä. Kasvatuksellinen tarve korosti katsojien keskinäisiä suhteita ja yhteenkuuluvuutta pikemminkin kuin yksittäisen katsojan suhdetta esitettyyn elokuvaan ja sen sisältöön. ${ }^{2}$

"Payne Fund Studies" Yhdysvalloissa 1930-luvun alkupuolella on esimerkki toisentyyppisestä kasvatusperinteen taustasta. ${ }^{3}$ Tutkimukset väittivät, että lapset ja siirtolaisten jälkeläiset sekä etenkin työväenluokkaan kuuluneet omasivat taipumuksen ylisamastua elokuvien henkilöiden ja tapahtumien kanssa. Tästä syystä elokuvat vaikuttivat voimakkaasti asenteisiin ja uskomuksiin. Näistä lähtökohdista elokuvakasvatus otti tehtäväkseen harjoitustöiden, keskustelujen ja analyysien avulla istuttaa koululaisiin uusia elokuvien katsomistapoja. Asiaan kuului pyrkimys opettaa oppilaille tapoja tulkita sitä, mitä he näkivät ja kuulivat. Elokuvakasvatuksen tehtävänä oli kehittää oppilaiden esteettisiä taitoja.

Kolmas ja ajallisesti huomattavasti tuoreempi mediakasvatuksen perustelu liittyy uudistuneeseen käsitykseen lapsista niin medioiden kuin opetuksenkin vastaanottajina. Tämän periaatteen mukaan mediakasvatus on tarpeellista, koska lapset ovat aktiivisia merkitysten tuottajia. Toiseksi, tällainen tuotanto on luonteeltaan sosiaalista. Merkitys ajatellaan siis alati muuttuvana, muotoutuvana ja rakentuvana prosessina. Se ei ole joukko valmiita viestejä, jotka välittyvät eri kanavia pitkin valmistajilta ja lähettäjiltä vastaanottajille. Pikemminkin kysymyksessä on merkitysten tekeminen. Tästä johtuen tuon prosessin tulokset ovat aina "puolivalmiita". Tällaisessa vuorovaikutuksessa vastaanottaja on pikemminkin osallistuja kuin pelkkä omaksuja.

Mediakasvatuksen perinteessä voidaan lisäksi erottaa ainakin kolme tunnistettavaa suuntausta. ${ }^{4}$ Moraalisen paniikin perinne on perustanut väittämänsä sellaisiin tutkimuksiin, joissa esim. televisio-ohjelmien on todettu lisäävän väkivaltaista käyttäytymistä lapsissa. Ruiskeen perinne taas on korostanut medioiden seurauksia: esim. sitä, miten televisio vaikuttaa negatiivisesti perheeseen ja lasten älylliseen kehitykseen. Tässä perinteessä (jonka tunnetuimpia puolestapuhujia on Neil Postman) lukeminen on aina katselua parempi vaihtoehto kuluttaa aikaa. Koulu nähdään kuolevan kirjallisen kulttuurin viimeisenä linnakkeena. Tämän seurauksena mediat pyritään - ei sisällyttämään, vaan eliminoimaan koulun maailmasta. Tajuntateollisuuden perinne puolestaan on korostanut medioiden vaikutuksia käyttäjiensä asenteisiin, uskomuksiin ja mielipiteisiin.

Kaikille näille perinteille on yhteistä käsitys, jonka mukaan lasten ja medioiden keskinäiset suhteet nähdään suhteellisen yksinkertaisina ja yksioikoisina. Toisaalta juuri tämä yksinkertaisuus saattaa olla vetoava ja vaikuttava seikka suhteessa niihin, joille painettu sana yhä on tietyssä mielessä pyhää. Lisäksi mediat itse tuntuvat usein nostavan tutkimuskentästä esiin sellaisia "tuloksia", jotka tarjoavat yksinkertaisia malleja. Helposti ymmärrettävä, syin ja seurauksin perusteltavissa oleva ja selkeitä ehdotuksia vaativa tutkimus tulee kuulluksi, koska se on ikään kuin jo valmiiksi muokattuna medioiden omaa kieltä varten. Ottaakseen etäisyyttä medioiden toimintatavoista, niihin kohdistuvan opetuksen pitäisi tukeutua sellaiseen kulttuurisen kasvatuksen teoriaan ja tutkimukseen, joka tarjoaa kolmatta ulottuvuutta. Pyrkimyksenä tulisi olla murtautua ulos monimutkaisuuden ja selkeyden sekä teorian ja käytännön kaksijakoisista vastakohta-asetelmista. ${ }^{5}$

Edellä mainituille perinteille yhteisenä piirteenä on lisäksi se, että jokainen näistä suuntauksista näkee mediat hyvin voimakkaina ja vaikutuksiltaan lähinnä negatiivisina. Mediayleisöjen on siis oletettu koostuvan passiivisista kuluttajista, joiden joukossa erityisesti lapset ovat lukeutuneet vaaravyöhykkeeseen. Näin ollen mediakasvatuksenkin perustehtäväksi on tullut "rokottaminen": oppilaiden varustaminen sellaisin kyvyin, joilla nämä voisivat vastustaa medioiden monia negatiivisia vaikutuksia. Koululaitoksen kannalta tällainen "rokote" on lähinnä ollut kaksivaikutteista: joko on rokotettu huonoa taidetta ja ala-arvoista viihdettä vastaan tai sitten on rokotettu ideologista manipulointia vastaan, tulipa se sitten oikealta, keskeltä tai vasemmalta. Tämän periaatteen ongelmana on se, että lasten ja medioiden välinen suhde nähdään yhä kovin ahtaasti. Tällöin näet korostetaan vain vaikutusta (joka usein on vielä varsin lyhyen aikavälin vaikutusta) sekä yksioikoisia syy- ja seuraussuhteita.

Aktiivisuuden ja sosiaalisuuden huomioiva kasvatuspyrkimys lähtee peruskysymyksestä: onko mediakasvatuksen tehtävänä auttaa lasten kykyä vastaanottaa, vai lisätä kykyä vastustaa? Tämä puolestaan liittyy kysymykseen siitä, ovatko oppilaat passiivisia vastaanottajia luonnostaan? Ja onko opetuksen tehtävänä tästä syystä aktivoida heitä opettajan toimiessa eräänlaisena käynnistäjänä?

Medioiden työstämät merkitykset eivät ole jotakin, joka vain olisi sinällään “tekstissä” kuten elokuvassa tai TV-ohjelmassa sen tekijän "sanomana”. Lukijat ja katsojat tuottavat aktiivisessa vastaanotossaan merkityksiä tukeutumalla aikaisempaan tietoonsa. Se puolestaan perustuu sosiaaliseen ja kulttuuriseen kokemukseen (arkikokemukseen) sekä muista ohjelmista kumpuaviin kokemuksiin (luku- ja katselukokemuksiin). Tällä tavalla kokemusperäinen tieto on tietysti eri henkilöillä varsin erilaista. Yhtä kaikki se on kuitenkin sosiaalisen kanssakäymisen tuotetta ja siinä 
mielessä ainakin joiltakin osin jaettua tietoa, joka perustuu yhteisiin "mediakokemuksiin".

Mistä tuo tieto tulee, mihin se juureutuu ja miten se on muotoutunut? Tällaisten kysymysten avulla selvitellään sitä, miten "mediakieli" on sekä sosiaalisesti että historiallisesti tuotettua ainesta eikä suinkaan neutraalia ja luonnollista. Mediaohjelmat (yhtä hyvin kuin onnistunut mediakasvatus esim. kouluissa) tarjoavat tilan, jonka puitteissa lapset voivat aktiivisella tavalla $\mathrm{ja}$ sosiaalisen kanssakäymisen keinoin neuvotella omia minuuksiaan. Medioilla ja niihin liittyvällä opetuksella on yksilöpsykologinen, jopa terapeuttinenkin funktionsa. Tämä lähtökohta ottaa huomioon sen, että lapset ovat hyvin heterogeeninen ryhmä oppilaita. Heillä voi olla paljonkin toisistaan poikkeavaa kulttuurisen tietämyksen kykyä eivätkä he ylimalkaan ole medioiden suhteen luonnostaan tietämättömiä.

\section{Media, kasvatus ja valta}

Medioiden merkityksiä ja niiden tuottamista sekä niiden luonnetta tuotteina voi lähestyä käsitteellisesti rajatuista näkökulmista: kieli, kerronta, instituutio, yleisö, esitystapa, yhteiskuntaluokka, sukupuoli, rotu, ikä, tuotantoprosessi, jne. ${ }^{6}$ Kaikki nämä ovat sellaisia avainkäsitteitä, joita voidaan lähestyä varsin monin eri tavoin sekä medioiden läpi että käyttämällä niitä lähdemateriaalina. Myös sellaisia abstrakteja käsitteitä kuten esim. valta voidaan tarkastella vastaavalla tavalla.

Mediakasvatuksessa vallan problematiikkaa on totuttu lähestymään lähinnä kahdesta näkökulmasta: yleisön ja tuotannon. Tietyssä mielessä kumpaakin näistä on kuitenkin yhdistänyt sama pyrkimys vastata kysymykseen kenellä on valta pä̈̈ttää. Mediakasvatuksessa itse opetusinstituutio valtarakenteena on kuitenkin jäänyt vähälle huomiolle tai se on sivuutettu kokonaan.

Vallan käsite on perinteisesti noussut keskeiseen asemaan tutkittaessa elokuvien ja televisioohjelmien tuotantoa sekä niiden institutionaalisia, ideologisia ja poliittisia kytkentöjä; miten esim. yhteiskunnalliset instituutiot kuten valtio, oikeuslaitos, kirkko, jne. kontrolloivat audiovisuaalista ohjelma-aineistoa. Juuri tältä kannalta vallan käsite on usein nähty lähes saumattomassa yhteydessä talouden, ekonomian, rahan maailmaan. Elokuva tai ohjelma voi välittömästi toimia porttina myös tähän alueeseen: ohjelman auditiivinen ja visuaalinen ulkonäkö voi antaa jo viitteitä siihen, miten suurista summista on ollut kyse ohjelman valmistamisessa.

Toisaalta on kiinnitetty huomiota esimerkisi kysymykseen siitä, miksi, miten ja millä vaikutuksella mediatekstit (kuten elokuvat, televisio-ohjelmat jne.) määrittävät ennalta niiden mahdollisen vastaanoton. Eli karkeammin sanottuna; miten ohjelma manipuloi katsojansa katsomaan ja kuuntelemaan sitä ohjelmantekijöiden haluamalla tavalla. Valtadiskurssin kielellä: miten tekijät ja tuottajat "riistävät" katsojia?

Vastineena katsoja-kuluttajiin kohdistuneelle riistolle on sitten edelleen pohdittu sitä, mitä mahdollisuuksia yleisöllä (tai paremminkin yleisöillä) on ryhtyä katselu-, kuuntelu- ja tulkintatehtävään ikään kuin omista eikä yksin annetuista lähtökohdista käsin.? Voisi jopa yleistää, että viime vuosien kiinnostus mediayleisöjen katselutottumuksia ja tapoja kohtaan eritoten empiirisen aineiston keruuna, juontaa juurensa juuri tähän kysymykseen.

Tällainen tarkastelutapa on siirtänyt tulkinnallisen painopisteen tekstiä edeltävältä alueelta (sen tekemiseen ja tuottamiseen liittyvät tekijät) samoin kuin tekstin sisäiseltä alueelta (teksti itsessään analyysin kohteena) tekstin ja vastaanottajan välisen vuorovaikutuksen alueelle. Merkityksiä ei enää nähdä annettuina ja otettuina, vaan sellaisina, jotka muotoutuvat ja alkavat saada hahmoa vasta vastaanottotilanteissa. Toisin sanoen se, miten tekstit tulevat ymmärretyiksi ja tulkituiksi näyttää suuresti ja monin eri muodoin riippuvan siitä kontekstista, jossa vastaanottanut yleisö nuo tekstit kohtaa. ${ }^{8}$

Yhtäältä audiovisuaalinen teksti oletettiin vallan välikappaleeksi ja analyysin tehtävänä oli paljastaa tuon välineen taustalta sen tuottanut ja sitä ohjaillut valta. Toisaalta pohdittiin tuon vallan vaikutusta katsojiin (perusesimerkki tästä on väkivaltaan liittyvä vaikutustutkimus) sekä katsojien teoreettisia ja todellisia mahdollisuuksia harjoittaa "vasta-valtaa", analysoida ja tulkita ohjelmia omiin tarkoitusperiinsä.

Len Masterman kirjoittaa tästä ohjelman ja katsojan "vuorovaikutusperiaatteesta" siirtäen asetelman kasvatusinstituution eli koulun kehyksiin:

\footnotetext{
Jos merkitys ei kerran piile tekstissä vaan yleisön ja tekstin vuorovaikutuksessa, niin tämä pätee myös opetustilanteeseen eikä vain televisionkatsomiseen. Onhan opettajien tunnettava käsiteltävän aiheen lisäksi myös oppilaiden panos siihen. [--] Lopuksi oppilaiden muuttaminen toisten lähettämien viestien passiivisista vastaanottajista aktiivisiksi merkityksen luojiksi - objekteista, joille kasvatus tapahtuu, tietoa luoviksi ja sitä omaksuviksi subjekteiksi - on kaikkien osapuolten kannalta vapauttava kokemus, joka edesauttanee aidon dialogin kehittymistä opetuksessa. [--] Mediakasvatuksen tarkoitus on varustaa oppilaat sellaisilla mediakyvyillä, joiden avulla he voivat kehiä sisään koodatun tekstin auki niin täydellisesti kuin mahdollista. Avoimeksi jää se, miten yleisö ja oppilaat tulkitsevat tekstin ja hyväksyvätkö he sen. ${ }^{9}$
}

Tällainen median ja koulun välinen suora rinnastus ei tietenkään ole Mastermanin keksimä: 
noin sata vuotta sitten jo Edison haaveili siitä, miten elokuva tulee muuttamaan kouluopetuksen luonteen ja kenties lopulta kokonaan korvaamaan esimerkiksi oppikirjat.

Vaikka Mastermanin luonnostelemaa rinnastusta median ja koulun kesken voikin pitää monessa mielessä ongelmallisena, ainakin valta-asetelman kannalta se avaa kiinnostavan lähtökohdan: millä tavalla valtarakennetta on arvioitava uudelleen, jos katselutilanteen vastavuoroisuus rinnastetaan opetustilanteen vastavuoroisuuden kanssa? Jos tavoitteena on muuttaa dialogiin osallistuvat tasavertaisiksi subjekteiksi niin mitä se merkitsee pyrkimykselle "varustautua edellytetyin mediakyvyin"?

Ilmeisestikään ei riitä, että vain luotamme mediatekstien vastaanoton dialogisuuteen. Uusi oppimistilanne ei vielä synny siitä, että tekstien itsensä avulla kouluun uskotaan samalla tuotavan vastavuoroisuuden periaate opetukseen ja oppimiseen yleensä. Toinen ongelma piilee käsitteessä "mediakyvyin varustautuminen". Medioiden monine eri muotoineen tänä päivänä hallitsema koulun ulkopuolinen maailma nähdään tällöin jatkuvana kriisinä, josta selviytymiseksi on "varustauduttava". On vaarana, että koulu tulee entisestään korostaneeksi omaa luonnettaan eräänlaisena kasarmina - tai vielä kärkevämmin, ja näin avaten ensimmäisen suoran linkin tässä tekstissä käsiteltävään esimerkkielokuvaan - keskitysleirinä.

\section{Valta, vapaus ja vastuun kahleet}

Koulunkäynti rinnasteisena pikemminkin sodankäynnin kuin median kanssa toimii tässä kontekstina sille, miten vallan abstraktia kysymystä voi lähestyä konkreettisesti käyttämällä välineenä elokuvaa tai televisio-ohjelmaa. ${ }^{10}$ Tässä tekstissä esimerkkinä on Steven Spielbergin ohjaama elokuva Auringon valtakunta (Empire of the Sun, USA 1987).

Elokuva perustuu J.G. Ballardin samannimiseen (ja useasti palkittuun, vahvasti omaelämäkerralliseen) romaaniin, joka ilmestyi vuonna 1984 ja suomennettiin vuonna 1988. Vuonna 1991 Ballardilta ilmestyi Auringon valtakunnan "jatko-osa" (The Kindness of Women), jossa hän niin ikään omaelämäkerrallisen aineiston avulla ja minämuodossa kuvaa päähenkilönsä, James Grahamin vaiheita sotavuosien jälkeen Englannissa ja Pohjois-Amerikassa. Kiinnostavalla tavalla itse-reflektiivisesti Ballard kuvaa jatko-osan lopussa myös Auringon valtakunta -elokuvan kuvauksia ja sitä, miten palanen hänen kuvittelemaansa Shanghaita heräsi henkiin Lontoon liepeillä, Sheppertonin elokuvastudioilla.

Auringon valtakunta kuvaa 11/12-vuotiaan Jimin elämää Shanghaissa ja sen lähistöllä joululta
1941 kesään 1945 sekä sodan päättymiseen saakka. Tarinan nimi, "Auringon valtakunta", "Empire of the Sun" voidaan lukea monimerkityksisenä. Kirjaimellisesti tarinan sisäisessä maailmassa se tarkoittaa Nantaon olympiastadionia, jonne kerättyä britti-imperiumin omaisuutta (autoja, pianoja, huonekaluja, kristallikruunuja, jne.) valaisee Nagasakiin pudotetun atomipommin pieni aurinko. Valtakunnan, imperiumin käsite puolestaan viittaa suoraan britti-imperiumiin ja siihen, että Jim on britti, joka Kiinassa kuuluu etuoikeutettuun ja hallitsevaan luokkaan. Toisaalta se viittaa kontekstinsa kautta välittömästi myös toisaalle: sekä menneeseen kiinalaiseen keisarikuntaan että nykyiseen japanilaiseen keisarikuntaan - siis sodan (tai sotien) vastapuoliin. Historiallisten yhteyksien lisäksi, vallan akselilla, käsitteessä olioistuu ajatus "imperiumista", massiivisesta valtakunnasta yleensä.

Myös nimen jälkiosa, "sun" (aurinko) on monimerkityksinen. Ensinnäkin se viittaa (määrittelijänsä olinpaikasta riippuen joko "nousevan" tai "laskevan") auringon maahan, Japaniin. Toiseksi se viittaa Sun Yat-seniin, kumoukselliseen ja kansallismieliseen Kuomintang-johtajaan, joka oli korostanut perheen, suvun ja valtion itsenäistä roolia sekä jatkuvan vallankumouksen periaatetta yksilökeskeisyyden vastapainoksi. Sun Yat-senin merkitykseen 1920- ja 30-lukujen Kiinassa viittaa jo sekin, että esim. koululaisten oli opeteltava hänen poliittinen testamenttinsa ulkoa. Yhteys Suniin syntyy myös Tshiang Kai-Shekin kautta, jonka massiivista kuvaa pystytetään elokuvassa erään talon seinälle; Tshianghan oli jo Sunin aikana Kiinan asevoimien päällikkö

Kolmanneksi, nimi viittaa pojan valtakuntaan ("Empire of the Son") ja siihen, miten Jim erillään vanhemmistaan vähä vähältä oppii niitä vallan pelisääntöjä, joiden avulla poikuuden omnipotenssi muuttuu miehuuden impotenssiksi, fantasian kaikkivoipaisuus todellisuuteen kytkeytyväksi kyvyttömyydeksi. Tällä tasolla kyse on kasvamisja selviytymistarinasta, joka vaatii nostalgiseksi uhrikseen ei enempää eikä vähempää kuin lapsuuden. Neljänneksi, käsite "aurinko" voisi viitata energiana (kuumuus), valona (kirkkaus), muotona (pyöreys) ja väreinä (keltaisesta punaiseen) erilaisiin mytologioihin, joiden ilmausta lähes jokainen kuva tässä elokuvassa tavalla tai toisella on.

Ensimmäinen luku hengissä säilymisen tarinassa kuvaa alkutilannetta: kohteena on Jimin (tai kuten häntä lapsuuden alueella vielä kutsutaan, Jamien) turvattu ja turvallinen elämä osana "imperiumin" brittiyhteisöä ja omaa perhettään. Alkutilan harmoniaa seuraa klassiseen tyyliin tuon yhteyden hajoaminen ja välttämätön "matka" kohti tuntematonta (tässä tapauksessa aikuisuutta). 


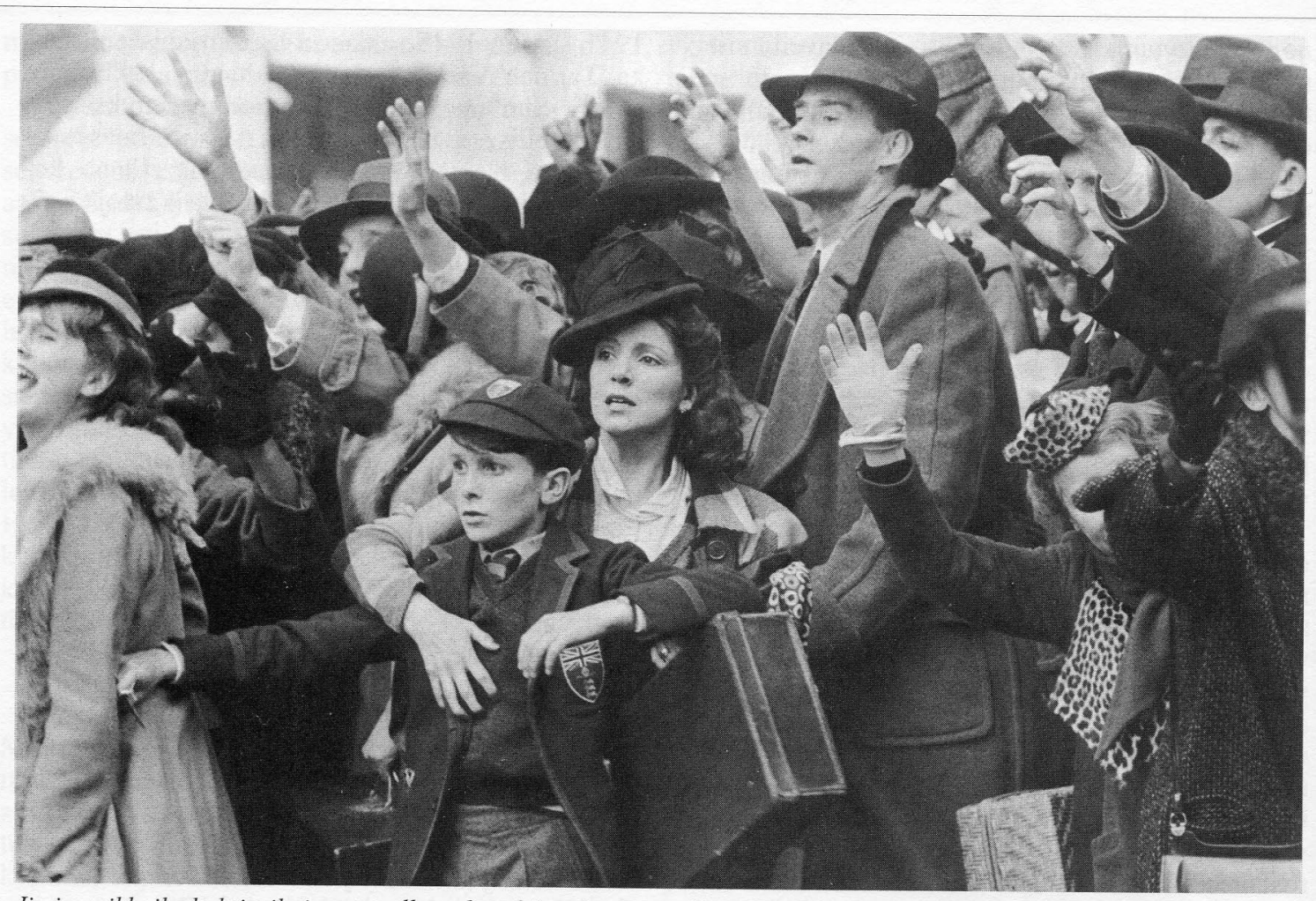

Jimin seikkailu kohti aikuisuutta alkaa, kun hän ajautuu erilleen vanhemmistaan. Kuva: Suomen elokuva-arkisto.

Alkutilanteen maailmassa todellisuus on korosteisen kaksijakoinen: yhtäällä on lapsuudenkodin brittisiirtokunnan järjestäytynyt ja eristäytynyt maailma. Toisaalla on ympäröivä paikallinen todellisuus, joka poliittisen kehityksen myötä vähä vähältä muuttuu uhkaavammaksi. Jimin sarjakuvista, leikkilentokoneista ja naamiaisjuhlista koostuvan maailman ja ulkoisen todellisuuden välissä on autonikkuna, jonka kautta Jim seuraa ympäröivää kiinalaista todellisuutta sen koko kirjavuudessa ikään kuin katsoisi elokuvaa; onhan se tyystin toisenlainen kuin maailma, jonka hän itse tuntee. Itse asiassa tähän piirteeseen viittaa jo Ballardin teksti: "Koko Shanghai oli muuttumassa uutisfilmiksi jota vuoti hänen [Jimin] omasta päästään." "Io tässä vaiheessa nämä todellisuudet liittyvät yhteen konkreettisten "esine-merkkien" kautta alkaen kiinalaisen kerjäläisen peltirasiasta: tämä kerjää juuri niitä kolikoita, joita Jimin isä käyttää golfpallojensa tiinä (ja jotka hän ilmeisen säännönmukaisesti lyö mailallaan uima-altaaseen). Sekä rahana että kuvana tuo kolikko on vallan ilmaus, joka välittömästi kytkeytyy imperiumiin. Tarinassa se liittää Jimin symbolisesti sekä omaan biologiseen isään että ideologiseen isään, kuninkaaseen. Vastaavanlainen isä-poika suhteen merkki on myös Jimin koulupuku. ${ }^{12}$

Elokuvassa kaikki suuret käännekohdat tapahtu- vat konkreettisina räjähdyksinä. Näistä ensimmäinen toimii samalla arjen harmonian katkaisijana. Räjähdys rikkoo todellisuuden tasot toisistaan erottavan läpinäkyvän lasipinnan, minkä seurauksena tarina alkaa liukua väistämättä reaalisen (ja samalla vallan) tasolta toiselle. Tässä kohtauksessa on kiinnostavaa se, miten Jim kokee itse olevansa syyllinen toisen todellisuuden väliin tuloon: vilkuttamalla lampullaan satamassa lipuvalle tykkiveneelle, hän uskoo itse aiheuttaneensa sen, että tykit alkavat pommittaa kaupunkia. Kaikkivoipa valta, jota hän on tuntenut omassa (fantasian ja imperiumin) maailmassaan ei tietenkään päde enää tähän todellisuuteen. Tämä yhteismitattomuus ei kuitenkaan vähennä sen kokemuksen todentuntua, jonka Jim elää ja jonka myötä hänen syyllisyytensä (kuvitellun) vallan "pitäjänä" yhä säilyy. ${ }^{13}$

Seurauksena on kaaos, joka johtaa Jimin ja vanhempien joutumiseen toisistaan erilleen. Ja jälleen pojalle tarjoutuu mahdollisuus syyttää tapahtuneesta itseään: jos hän haluaisi pitää kiinni äitinsä kädestä eikä takaisin fantasiaan vetävästä Zeroleikkilentokoneestaan, tuo ero jäisi toteutumatta. Enemmän kuin henkilöiden halut, tuota eroa kuitenkin vaatii elokuvan (fantasian) tarina itse; ilman eroa ei olisi (selviytymis)tarinaakaan.

Näin luonnostellun eron jälkeen Jimin paluu 
kotiin on paluuta tyhjyyteen ja tilanteeseen, jossa entinen valta-asetelma ei enää päde: kuuliainen, paikallinen palvelija on muuttunut käsketystä käskijäksi. Imperiumin vallasta on jäljellä vain kuoret, jotka Japanin keisarin uutena omaisuutena ovat vapaasti ryöstettävissä.

Selviytymistarinan seuraava askel edellyttää myös kodin ulkoisista puitteista luopumista; syödäkseen Jimin on pakko lähteä. Toinen kohtaaminen samalla tavalla äidittömän ja isättömän kiinalaisen ikätoverin kanssa tapahtuu kadulla, taustanaan valtava "Tuulen viemää" -elokuvan mainosjuliste. Takaa-ajon seurauksena Jim menettää sekä polkupyöränsä että kenkänsä, mutta häntä itseään, brittiläisenä koulupoikana, ei huoli kukaan - vapaaehtoisista antautumisyrityksistä huolimatta. Vasta paikalle osuva amerikkalaisten kuormaauto poimii pojan kyytiinsä, muttei nytkään hänen itsensä takia, vaan niiden merkkien ansiosta jotka hänellä on yllään: poika on muuttunut potentiaaliseksi kauppatavaraksi.

Piilopaikassaan Basie, toinen amerikkalaisista, tyhjentää tottunein sormin Jimin taskut ja yrittää seuraavana päivänä myydä pojan torilla - tuloksetta. Auton luona Basie heittää Jimille kolikon takaisin ikään kuin kieltäytyen hänelle tarjotusta keinotekoisesta isyydestä. Tästä Jim muistaa "ideologisen" taustansa ja lupaa viedä kauppatavaran etsijät kotikadulleen, jotta nämä eivät jättäisi häntä yksin. Kotitaloa kuitenkin asuvat nyt japanilaiset sotilaat, jotka pieksävät Basien Jimin silmien edessä. Ja taas Jim voi syyttää tapahtuneesta vain itseään: hän halusi takaisin kotitaloonsa yhtä paljon siksi, että amerikkalaiset pitäisivät hänet kuin siksi, että hän vielä toivoi tapaavansa vanhempansa. Yhtä vähän kuin kadulla marssinut japanilaisarmeija oli aiemmin valmis ottamaan "antautuvan" Jimin "pojakseen", yhtä vähän valkoisiin pukeutunut japanilaissotilas, johon he törmäävät Jimin entisen kotitalon ulko-ovella, on valmis Jimin äidiksi.

Vangeiksi joutumista seuraa kokoamisparakkien "esikoulu", missä Jim, Basien opastamana, oppii tulevan elämän perussääntöjä, hengissä pysymistä keinoja kaihtamatta ja kuoleman hyväksi käyttöä vailla eettistä tai moraalista etikettiä.

Sitten on edessä matka vankileirille. Jim on jäädä kuorma-auton kyydistä, mutta vielä kerran epätoivoisesti kaikkivoipaisuuteensa vedottuaan ("Tunnen seudun kuin omat taskuni, en eksy missään") hän pääsee "oppaaksi" matkalle, jonka aikana hänen tulevat (ja keskenään kilpailevat) huoltaja-hahmonsa, amerikkalainen Basie ja brittilääkäri Rawlins (kirjassa Ransome) tutustuvat toisiinsa. Leirille saavuttua Jim kohtaa heti myös kolmannen "isä-hahmonsa", leirin komentajan, kersantti Nagatan, jonka valta ja voima suhteessa Jimin fantasian kaikkivoipaisuuteen loppuu kes- ken Jimin ja lentokoneiden välisessä pastoraalisessa kohtaamisessa. Tässä elokuva tuntuu julistavan, että kaikesta elämän kaoottisuudesta huolimatta on yhä olemassa "taso", jolla vallan rajat ovat ylitettävissä: lentämisen maailma, elämä maanpinnan yläpuolella, irtautuminen kahlitsevasta kiinteästä materiasta.

Tämän jälkeen tarinassa siirrytään suoraan kolme vuotta eteenpäin, vuoteen 1945. Elämä vankileirillä on jatkunut jo pitkään omissa uomissaan; itse asiassa Spielberg antaa siitä varsin omintakeisen kuvan - ikään kuin kysymyksessä olisi normaali amerikkalaisen pikkukaupungin arjen kuvaus:

Auringon valtakunnan lähes perverssillä tavalla ironinen saavutus on epäilemättä sen taito esittää meille historiamme todellinen ja mahdoton trauma eli keskitysleiri nostalgisena kohteena; meille, jotka elämme postmodernin nostalgian aikaa eli sitä, jolloin kadonneen ajan lukemattomat kuvat tarjoutuvat halun kohteiksi ja syiksi. [--] Sellainen on keskitysleirin kuvaus, siis ilmiön, joka epäilemättä edustaa tämän vuosisadan traumaattista "reaalista" eli sitä, mikä aina "palaa samanlaisena" kaikissa sosiaalisissa järjestelmissä. ${ }^{14}$

Jim toimittaa kiillottamansa kengät kylpevälle Nagatalle ja varastaa samalla tämän saippuan. Sairaalassa tutustumme lähemmin tri Rawlinsiin, joka on omaksunut myös Jimin opettajan roolin; häneltä Jim varastaa pullonkorkin. Lopulta olemme amerikkalaisten parakissa Basien luona, jolle Jim kerää tavaroita. Samalla asemoidaan Jimin lopullista "miehuuskoetta", jonka tuloksena hänellä saattaisi olla - ei yksin paikka Basien luona, vaan myös toveruus tämän pakokumppanina. Sitä ennen Jimin on kuitenkin puututtava asioihin $\mathrm{Na}$ gatan ja Rawlinsin ottaessa yhteen. Palkkioksi Jim saa kauan havittelemansa golfkengät, jotka miehuuden merkkinä valmistavat tulevaa varten ja isyyden merkkinä toimivat muistona menneestä.

Kohtaus leirin ulkopuolella, piikkilanka-aitojen takana on kuin suora sovellutus Arnold van Gennepin siirtymäriittejä käsittelevästä tutkimuksesta. ${ }^{15}$ Voittaakseen uuden aseman yhteisössä Jim joutuu tilapäisesti sen ulkopuolelle, "rajatilaan", missä hänen on suoriuduttava tehtävästä (fasaaniansojen vieminen). Alkuasukaskansojen murrosikäisten tapaan Jimkin "maskeeraa" kasvonsa mudalla ja myös hänellä on mystinen ulkopuolinen auttaja (suojellen häntä ankaran isän aseelta) läheisen lentokentän japanilaispoika, joka myös harrastaa lennokkeja. Jim suoriutuu ja palaa voitonmarssin tahdeissa uuteen kotiinsa, amerikkalaisten parakkiin. Brittien parakista poiketen tämä ympäristö onkin tyystin miesten hallitsema valtakunta. Harmoninen, pakosuunnitelmien parissa sujuva elämä maskuliinisessa "jenkkilässä" jää tietysti lyhytaikaiseksi iloksi. Hallitsevan isän 
oikeuksin Nagata tulee etsimään tuota kohtalokasta, varastettua saippuaansa, joka niin muodoltaan kuin funktioltaankin on Basien ja Jimin isä-poika suhdetta symboloineen, aiemmin esiintyneen kolikon pehmeämpi ja tuoksuvampi toisinto.

Tällä kertaa Jimin kumarrukset eivät pelasta Basietä niin kuin ne olivat aiemmin pelastaneet tri Rawlinsin. Ja taas poika saa tilaisuuden syyttää tapahtuneesta itseään. Ellei hän olisi halunnut miellyttää Basietä viemällä tälle Nagatalta varastamansa saippuan, tapahtumat olisi kenties voitu välttää. Näin jokaista tekoa, jonka Jim tekee yrittäessään saada "todellisuuden" käyttäytymään haluamallaan tavalla (yrittäessään noudattaa kaikkivoipaisuuden periaatettaan), seuraa ikään kuin todellisuudesta tuleva vallan vastaisku. Sen edessä Jimin ei auta muu kuin todeta voimattomuutensa, oman valtansa mitättömyys.

\section{Aurinkolasien valtakunta}

Auringon Valtakunnassa vallan representaatiot yksilöityvät ja samalla jakautuvat hienosyisemmin; yhdestä ja yhtenäisestä "vallasta" ei oikeastaan voi enää puhua - muuten kuin siinä mielessä, että noita kaikkia alueita yhdistävät isyyden ja sodan perusteemat. Ensinnäkin voidaan puhua traditionaalisesta vallasta, joka olioistuu erilaisina instituutioihin liittyvinä mystiikkoina. Kyse on symbolisesta, ritualistisesta ja karismaattisesta vallasta; vallasta "sinänsä". Tällä tasolla henkilöt eivät ole vallan käyttäjiä, vaan valta ikään kuin puhuu henkilöittensä (kuten Laki tuomarien) kautta. Traditionaalisen vallan akselille kuuluvat "imperiumeiden" edustajat, Auringon valtakunnassa yhtä lailla Jimin isä kuin vankileirin päällikkö, kersantti Nagatakin. Tällä tasolla Nagatankin voi siis nähdä Jimin ankarana isänä, ja Nagatan ainoat englanninkieliset sanat Jimille ("Difficult boy", "Vaikea poika") heidän lopulta erotessa saavat uudenlaista merkitystä.

Toisella tasolla voidaan puhua manipuloivasta vallasta, joka perustuu suoraan alamaisten ohjailuun, säätelyyn ja manipulointiin. Tämä vallan muoto on luonteeltaan opportunistista ja kyynistä, se omaksuu erilaisia rooleja ja tähtää etupäässä vain oman voiton pyyntiin. Tätä vallan tasoa elokuvassa edustaa amerikkalainen Basie.

Kolmas taso on totalitaarinen valta. Se perustuu auktoriteettiin, joka näkee alamaiset tietämättöminä, oppimattomina ja kasvatettavina. Auktoriteetilla itsellään on sekä etuoikeutettu suhde tietoon että merkit tuon suhteen pätevyydestä. Tätä vallan tasoa elokuvassa edustaa brittilääkäri Rawlins. ${ }^{16}$

Jim, tehtävänään selviytyä "elämän korkeakoulusta", käy tuota vankileirikoulua sukkuloiden ja joutuen tekemisiin kaikkien näiden valtatasojen ja niitä edustavien miesten kanssa. Valtatasojen olioistunut läsnäolo (ja samalla niiden alituinen keskinäinen kilpailu) tekee Jimin "koulusta" totalitaarisen universumin. Hän voi yrittää selviytyä vain turvautumalla elementteihin, jotka estävät todellisuuden täydellisen pirstoutumisen. Kaikki nämä elementit elokuva kytkee suoraan Jimin lapsuuteen, "fantasian kaikkivoipaisuuteen": vanerinen matkalaukku, jossa Jim kantaa vanhaa koulupukua, leluja ja valokuvia tuosta maailmasta; lentokoneet ja lentäminen jotka konkreettisesti ilmentävät kaikkivoipaisuuden saavuttamista maan

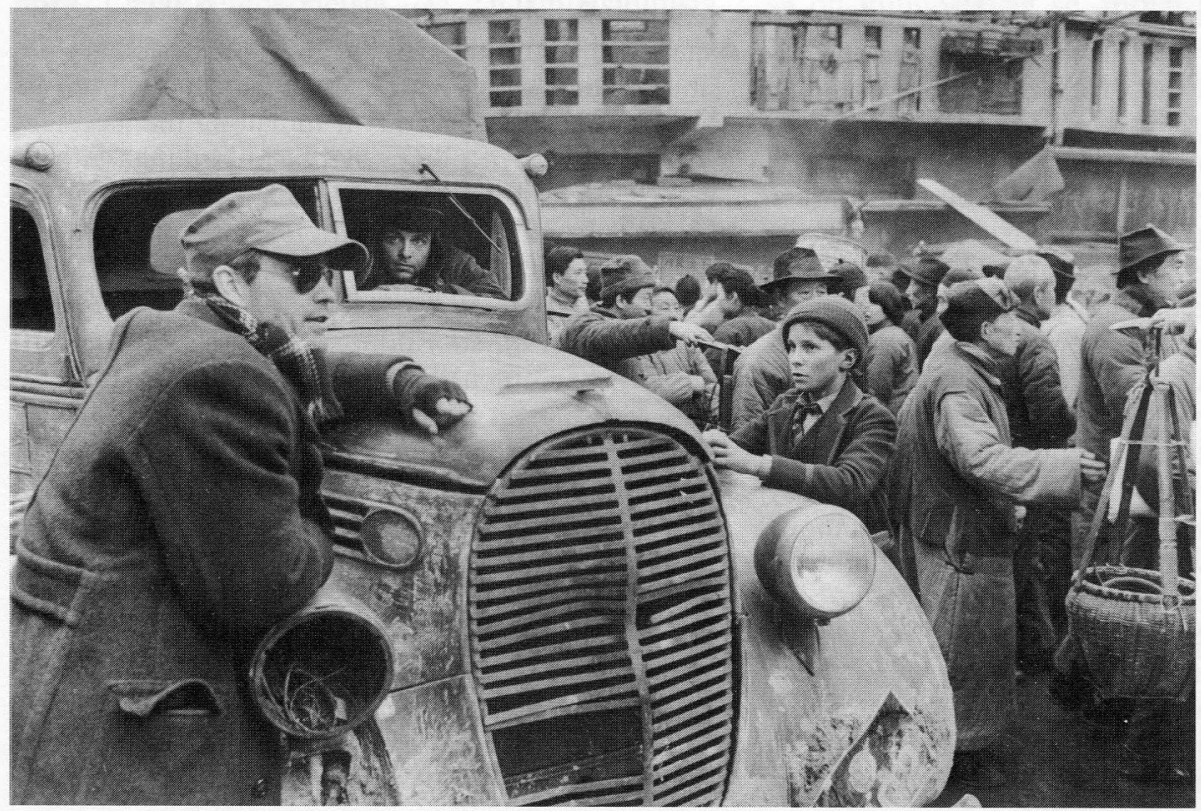

Jim amerikkalaisen "isänsä kanssa. Kuva: Suomen elokuva-arkisto. 


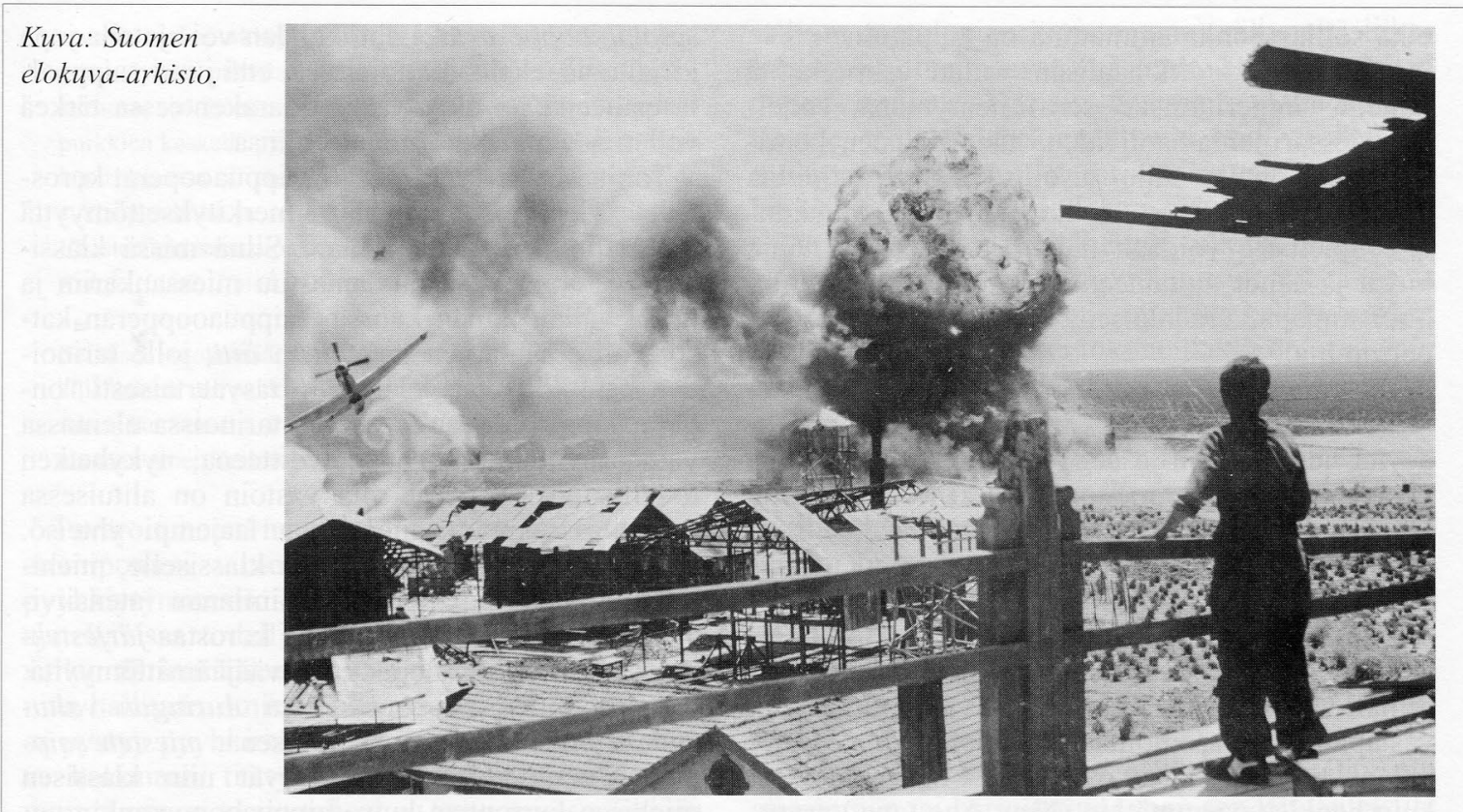

kahleista vapautumisen kautta; katedraalikoulussa opittu laulu, jne.

Fantasian ja todellisuuden, sukupuolettoman lapsuuden ja maskuliinisen aikuisuuden yhteismitattomuus näkyy kaikkein selvimmin "päälle päin": päästyään miesten maailmaan eli amerikkalaisten parakkiin, Jim saa ylleen samanlaisen lippalakin kuin Basiellä ja monta numeroa liian suuret sotilashousut. Tätä aiemmin muutosprosessi on tapahtunut pala palalta: ensin kengät, joilla muutenkin on varsin keskeinen rooli (niin kirjassa kuin elokuvassakin), ja sitten nahkatakki, joka puolestaan kytkee Jimin pitkään yksinäisten sankarien ja "nahkasukkien" saagaan. Tähän uuteen ulkokuoreen kuuluvat myös aurinkolasit, jotka Jim elokuvan alkupuolella oli löytänyt kotitalonsa kuivuneen uima-altaan pohjalta ja jotka myöhemmin kuuluivat Basielle. Kolikon tavoin aurinkolasit viittaavat merkkinä yhtäältä imperiumiin ja toisaalta isyyteen, tällä kertaa sen amerikkalaiseen muunnokseen.

Tarinan kliimaksi tapahtuu heti sen jälkeen, kun Jim joutuu Basien, amerikkalaisen “isänsä” omaisuuden puolustamisessa epäonnistuttuaan jälleen kerran orvoksi. Jäähyväiset lapsuudelle toteutuvat kerronnallisena sarjana. Vielä kerran Jim palaa menneeseen katedraalikoulussa oppimansa hymnin muodossa. Tarinassa ympäröivän todellisuuden tasolta laulu pian "kohoaa" fantasian siivin yläilmoihin ja saa rajat ylittävän, kollektiivisen jäähyväislaulun luonteen, johon tuntuvat yhtyvän niin vangit kuin vartijatkin.

Nostalginen tunnelma katkeaa kuin leikaten i1massa räjähtävään lentokoneeseen. Jälleen kerran,

Hollywood-elokuvan perinteelle uskollisena, "vapauttajat" saapuvat paikalle Yhdysvaltain ilmavoimien ominaisuudessa. Toisiaan seuraavat räjähdykset, yli leirin pyyhkivät hävittäjälentokoneet, rauniotalon katolla huitova Jim yhdessä katsojien kanssa jakavat yhteisen kaikkivoipaisuuden kokemuksen ikään kuin viimeisenä etappina siirtymässä lapsuuden valtakunnasta kohti "tuntematonta tulevaisuutta". Tietysti sekin on mitä vähimmässä määrin tuntematon: vasta USA:n ilmavoimien upseeri ottaa vastaan Jimin "Minä antaudun!" -huokauksen saatteleman Jerzee-juoman. Kohtaus muistuttaa suuresti erään varhaisemman, vastaavantyyppisen selviytymistarinan loppua, Peter Brookin elokuvaa Kärpästen herra (Lord of the Flies, Iso-Britannia 1963), joka tunnetusti perustuu William Gouldingin samannimiseen romaaniin. Tämäkin tarina on sijoitettu toisen maailmansodan kehikkoon ja siinä joukko sisäoppilaitoksen poikia haaksirikkoutuu autiolle saarelle, missä heidän on opittava tulemaan toimeen sivistyksen ulkopuolella, luonnon armoilla.

Kasvu ja selviytymistarina näyttäytyy myös paradoksina: selviytymisen ehtona on tuosta fantasian kaikkivoipaisuuden kokemuksesta luopuminen ja olemassaolevien valtarakenteiden - niin traditionaalisten, manipuloivien kuin totalitaaristenkin - edessä taipuminen. Auringon valtakuntaa huomattavasti painokkaammin Kärpästen herra on kuvaus juuri tällaisesta taipumisesta: elämä luonnon armoilla johtaa valta-asetelman polarisoitumiseen, persoonattoman kollektiivin syntymiseen ja yksilöiden tuhoutumiseen. Tässä valossa saarelle rantautunut valkoinen amiraali on Vapahtaja 
eikä sotilas, jonka ammattina on tappaminen.

Edellä oli traditionaalisen vallan esimerkkinä puhetta "imperiumista" sen ilmentymänä. Todellisuudessa olemassaolleiden, historiallisten keisarikuntien ohella tälle tasolle voidaan sijoittaa myös kuvan ja äänen "audiovisuaalinen valtakunta”. Spielberg voidaan nähdä jo itsessään nämä kuvat ja äänet tuottaneen Hollywood-imperiumin olioistumana, eräänlaisena Steven Spielberg-imperiumina.

Tätä imperiumia on luonnehdittu esimerkiksi seuraavasti: ${ }^{17}$ Spielberg korostaa perheen keskeisyyttä huolenpidon ja hellyyden alueena; tällaista yksikköä uhkaavat monet ulkoiset vaarat (perhe nähdään eräänlaisena taistelukenttänä, jossa "ydin" vastustaa ulkopuolelta tulevaa). Kuvauksen keskiössä on siis harmoninen ja romanttissentimentaalinen yksityisalue. Luonnon ja tunteiden alue idealisoidaan vastakohtana järjen hallitsemalle "kulttuurille" ja ahdistavan nykyhetken vastapainoksi asemoidaan huolettomana nähty menneisyys. Keskeisiä ovat lisäksi niin ekologiset kuin henkistyneemmätkin (New Age yms.) arvot.

Näistä lähtökohdista Spielbergin maailma näyttäytyy korosteisen kaksijakoisena. Erilaiset vastaparit määrittyvät keskinäissuhteissaan:

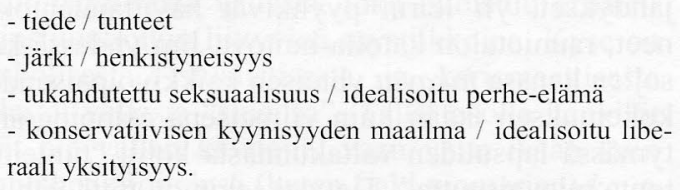

Auringon valtakunta on tästä näkökulmasta eräänlainen Spielbergin 400 kepposta (Francois Truffaut, Les quatre cents coups, Ranska 1959). Esimerkiksi Dennis Turner on puhunut Truffaut'n yhteydessä James Fenimore Cooperin "nahkasukka-saagasta" ja "jalosta villistä", jonka hahmossa Turner näkee amerikkalaisen vapauden mytologian kiteytyneimmillään. ${ }^{18}$ Turner vertaa Truffaut'n päähenkilöä, Antoine Doinelia, nykypäivän Hirventappajaan, joka ei löydä kotiaan sen enempää sivilisaation kuin aikuisuudenkaan (miehisyyden) maailmoista. Seurauksena on kulttuurinen outsider, syrjäläinen, ikuinen lapsi, Peter Pan. Niin Truffaut'lle kuin Spielbergillekin lapsi näyttää olevan suhteessa yhteiskuntaan ulkopuolinen par excellence. Vastaavasti koti tai koululuokka (eli nuo keskeisimmät yhteiskuntaan sopeuttavat ympäristöt) saavat vankilan piirteitä vastakohtana esim. elokuvateatterille tai fantasian kaikkivoipaisuudelle laajemminkin. Tässä mielessä niin Truffaut'n kuin Spielberginkin "nahkatakki-sankarit" (Antoine ja Jim) polveutuvat samaisesta James Fenimore Cooperin stalker-hahmosta.

Tekijyyden lisäksi kosketuskohtia voi etsiä lajityypin (genre) kautta, esim. tässä tapauksessa saippuaoopperasta. Lähtökohdan voi ajatella jopa kirjaimelliseksi siinä mielessä, että juuri saippualla esineenä on elokuvan tarinarakenteessa tärkeä vallan asemia esiin tuova roolinsa.

Tania Modleskin mukaan saippuaooperat korostavat yksilöllisen elämän merkityksettömyyttä kollektiivin kustannuksella. ${ }^{19}$ Siinä missä klassisen kerronnan katsoja samastuu miessankariin ja jakaa vallan tämän kanssa, saippuaoopperan katsoja on eräänlainen ideaalinen äiti, jolle tarinoiden henkilöt ovat ikään kuin tasvaertaisesti "ongelmalapsia". Ideaaliperhe on tarinoissa olemassa vain saavuttamattomana tavoitteena; nykyhetken todellisuudessa perhe sitä vastoin on alituisessa kriisitilassa muotoaan hakeva laajempi yhteisö. Saippuaooppera on vastakohta klassiselle, miehiselle elokuvatarinalle, joka toiminnan intensiivisyydellä ja dialogin puutteella korostaa järjestyksen palauttamisen nopeutta ja vääjäämättömyyttä.

Lajityypillisessä kontekstissa Auringon valtakuntaa voisi lukea maskuliinisena, miesten saippuaoopperana, jossa yhteytyvät niin klassisen miehisen kerronnan kuin saippuaoopperankin perustuntomerkit. Tekstin itsensä asemoima katsoja ei ole Modleskin määrittelemä ideaali, "vapaamielinen äiti", muttei myöskään miespuoliseen sankariin samastuva vallan jakaja. Millainen hän sitten on? Kenties lähimpänä vertauskohtana voisi olla vaihtoehtojen eräänlainen "synteesi", liberaali isä, joka Jimin selviytymistarinassa kokee aineksia omasta henkilökohtaisesta menneisyydestään, mutta samalla myös elokuvan "isähahmojen", vallan eri tasojen kautta aineksia omasta nykyisyydestään.

\section{Lentäen voitamme!}

Henkilöiden todellisuussuhde eli se, miten he pysyvät kaaoksenkin keskellä edes jollakin tavalla rationaalisessa yhteydessä ympäröivään maailmaan, perustuu Auringon valtakunnassa "pieniin palasiin" todellisuutta. Noita "maailmanpaloja" kerätään ja varastoidaan; tällä tavalla todellisuus näyttäytyy tavaroituneena ja fetisoituneena viitaten yksilöiden pyrkimykseen hallita sitä tavalla tai toisella sekä käyttää "omaa" valtaansa sen suhteen. Elokuvan tavarat ovat korostettuja esinemerkkejä: vankileirin "kulutushyödykkeet”, Jimin vanerilaukku sisältöineen, Nantaon stadion (joka rakennettiin Madame Tshiang Kai-Shekin käskystä siinä toivossa, että Kiina olisi saanut vuoden 1940 olympiakisat; nehän myönnetiin Helsingille) ja eritoten taivaalta putoilevat "jääkaapit":

Säiliö oli hajonnut törmäyksen voimasta. Jim laskeutui auringon paahtamaa kanavan kuvetta ja kyykistyi lieriön avoimen suun eteen. Hänen ympärillään ojanpohjalla oli aarteen 
arvosta ruokapurkkeja ja savukepakkauksia. Säiliö oli tungettu täyteen pahvilaatikoita joista yksi oli irronnut kärkikartiosta levittäen sisältönsä ympäristöön. Jim konttasi purkkien keskellä pyyhkien silmiään jotta voisi lukea nimilaput. Maassa oli purkeittain Spamia, Klimia ja Nescaféta, suklaapatukoita ja sellofaaniin käärittyjä Lucky Strike- ja Chesterfield-savukepakkauksia sekä nipuittain Valittuja Paloja, Lifeä, Timeä ja Saturday Evening Postia.

Sellaisen ruokamäärän näkeminen sai Jimin ymmälleen, sillä hänen oli pakko valita, ja sitä hän ei ollut joutunut tekemään vuosiin. Purkit ja paketit olivat jääkylmiä, kuin suoraan amerikkalaisesta jääkaapista (s. 274).

Tavaroituneen maailman vastineena on sitten atomipommi viitteenä kaiken totaalisesta poispyø̆kiytymisestä. Tässä mielessä atomipommi on ajateltavissa todellisuuden pyyhekumina ja siten vallan äärimmäisenä muotona. Sen avulla maailmaa hallitaan omistamalla väline, joka tarvittaessa pystyy pyyhkimään "pieniä palasia" maailmasta kokonaan tiettymättömiin. Tarinassa atomipommi saa, ei yksin tuhoavan vaan myös säilövän merkityksensä. Elokuvassa Jim toteaa omia käsiään tuijottaen: “Opin tänään uuden sanan, atomipommi. Se oli kuin valkea valo taivaalla. Niin kuin Jumala olisi ottanut valokuvaa." Elokuvassa atomipommi kytketään näin yhtäältä sanaan ja toisaalta kuvaan. Kirjassa rajaukset ovat eri tasolla: "Valkoinen valo peitti Shanghain, voimakkaampi kuin aurinko. Varmaan Jumala halusi nähdä kaiken" (s. 310).

Paul Virilio otsikoi teoksensa War and Cinema toisen luvun lainauksella Nam June Paikilta: "Elokuva ei ole 'Minä näen', vaan 'Minä lennän'."20 Tuossa luvussa Virilio kuvailee sellaisia havaitsemisen logistiikkaan vaikuttaneita tekijöitä, joiden seurauksena inhimillinen kapasiteetti tälläkin alueella sananmukaisesti räjähti ensimmäisen maailmansodan aikana. Virilio pohtii, miten elokuvan ja ilmailun välinen metaforinen suhde piirtyy uudella tavalla näkyväksi monilla tasoilla, ulottuen tekniikan kehityksestä eri taidemuotojen sisältöihin saakka. Taustalla on tietysti ajaton myytti, jonka yhtenä ilmauksena voisi pitää siivekästä, vailla ajan ja paikan rajoituksia liikkumaan pystyvää ihmishahmoa - siis enkeliä. Riippumattomuuden lisäksi enkelissä olioistuvat hyvän ja pahan sekä oikeudenmukaisuuden ja vääryyden vastakohta-asetelmat, valkoisen ja mustan enkelin iätön kaksinkamppailu.

Mytologian aatteellinen välimatka lentämisen käytännöstä käy ilmi esimerkiksi siitä, miten tarkasti varjeltuja "kansallisia" omaisuuksia valtioiden ilmatilat ovat. Vieraan ilma-aluksen ("mustan enkelin") tunkeutuminen toisen valtion ilmatilaan voi olla riittävä ehto sen alas ampumiseen. Toiseksi, kenties vahvimmin kansallisena (ja kan- sallisen mytologian koristamana) säilyneitä liiketoiminnan alueita ovat yhä lentoyhtiöt (alkaen jo niiden nimistä: Finnair, Swissair, Alitalia, Air France, jne.). Ikään kuin ilmailu olisi virallistettu irvikuva vapauden metaforiikan ja taloudellis-poliittisen sulkeutuneisuuden ristiriidoille.

Tässä suhteessa Spielbergin tulkinta nojaa tietysti molemmin jaloin mytologiaan. Tästä osoituksena on jo se, että Jimin mielestä kaikki lentäjät ovat samanarvoisia. Lentokoneillakin on eroa vain niiden tehon ja suorituskyvyn, ei kansallisuuden mukaan. Isyyden ohella Basie, Nagata ja Rawlins kuuluvat samaan vankileiriin, koska heidät on kahlittu maahan. Elokuvan lentäjät ovat kaikki persoonattomia, lentäjän univormuun ja suojalaseihin pukeutuneita, ikään kuin osaksi lentämäänsä konetta kasvaneita olioita. Kasvun tarina on näin ollen ja taas myös Oidipuksen tarina. Kohdatessaan vanhempansa elokuvan lopussa, Jim painautuu hitaasti vasten äitiään samalla tuijottaen taivaalle. ${ }^{21}$

Valtaa koskeva keskeinen kysymys ei liity sen alkuperään tai harjoittajiin, vaan sen käytänteisiin. Yleisellä tasolla ne jakaantuvat kolmelle alueelle: tilan jaotteluun, ajan järjestelyyn ja aika-tilojen rakenteluun..$^{22}$ Esimerkkinä voisi olla tämän tekstin alussa esitelty, varhaiseen elokuvatoimintaan liittynyt keskustelu. Elokuvien tarkastamista ja sensuuria vaatineet pohdiskelut viittasivat juuri siihen, millaisin keinoin voitaisiin entistä paremmin kontrolloida sekä sitä tilaa (elokuvateatterit) että aikaa (illat), jonka esim. lapsikatsojat elokvanäytännöissä viettivät. Tällaisen asetelman vastapariksi muotoutui ikään kuin itsestään toinen tila-aika -rakenne: koulu-päivä.

Kysymys vallan käytänteistä tarkoittaa siis sen selvittämistä, mikä on kulloinenkin tapahtuma tai teko ja mikä väline, joka tuohon tapahtumaan tai tekoon liittyy. Viime kädessä vallan rakenteet rajaavat itse tiedon aluetta: yhtäältä sitä, mitä näemme ja toisaalta sitä, mitä voimme sanoa. Näkemisen ja puhumisen kysymykset ovat samalla valon, katseen suuntaamisen, terävyyden ja kielen eri ominaisuuksien kysymyksiä. Instituutioiden koneistot ja säädökset muokkaavat näkyvyyden kenttiä ja sanomisen järjestelmiä, toisin sanoen sekä sitä, mikä näkyy (näkymä) että sitä, mikä kuuluu (lausuma). Tietoisuus vallan jaottelevasta, järjestelevästä ja muokkaavasta läsnäolosta lähtee siitä, että havaintoja ei enää tehdä kuten ennen eikä väittämiä esitetä siten kuin niitä on totuttu esittämään. Asioita siis sekä katsotaan että selitetään toisin. Asetelma näyttää pakosta asemoituvan dualistisesti, mutta kuten Deleuze osoittaa, tällaisen dualismin ei tarvitse olla suljettu vastaparirakenne (kuten Descartesilla tai Kantilla) tai ykseyteen tähtäävä (kuten Bergsonilla tai Spinozalla). Kolmantena vaihtoehtona (Foucault) on 


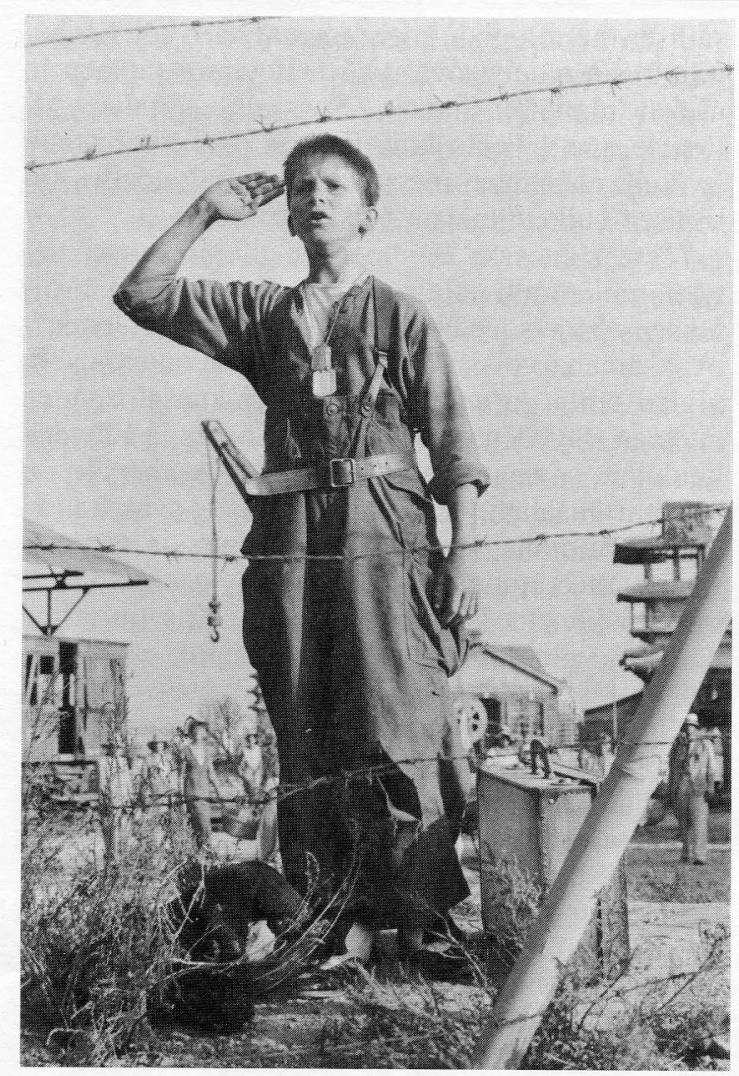

Kuva: Suomen elokuva-arkisto.

"kahtalaiseen moninaisuuteen" johtava dualismi: "lausumat ovat olemassa vain diskursiivisessa ja näkymät ei-diskursiivisessa moninaisuudessa", jotka sitten johtavat eteenpäin erilaisten voimien välisten suhteiden moninaisuuteen. ${ }^{23}$

Auringon valtakunta itsessään on "oppikirja" siitä, miten elokuva kohdistaa huomionsa pojan kasvuprosessin avulla (ympäristönä miehisistä maailmoista miehisin eli sota ja traumaattisista maailmoista traumaattisin eli vankileiri) juuri näihin näkemisen ja kielen valtarakenteisiin. Konkreettisin merkki on Nagasakin atomipommi, joka elokuvassa solmii yhteen sekä kysymyksen kielestä ("Opin tänään uuden sanan...") että kysymyksen kuvasta ("...kuin Jumala olisi ottanut valokuvaa"). Nagatan maailma on ehdottomassa dualismissaan cartesiolainen. Rawlinsin maailma taas tähtää sellaiseen ykseyteen, jota esim. brittiimperiumi edustaa. Basie ja elokuvan koko tietty "amerikkalaisuus" taas on selvästi moninaisuuteen ja moniarvoisuuteen pyrkivää dualismia, joka on sitä vain tilapäisesti, olosuhteiden pakosta. Lentämisen tapaan myös tuo Spielbergin amerikkalaisuus on pikemminkin myyttien ja fantasian maailma kuin elävää arkitodellisuutta. ${ }^{24}$ Myös tällä tasolla fantasian rajattomuus ja runsaus piir- tyy ympäröivän arjen vankeutta ja niukkuutta vasten. Erilaisia dualismeja olennaisempaa on kuitenkin niissä tapahtuva muutos.

Auringon valtakunnan loppujaksot kertovat suoraan siitä, miten mieheksi tulemisen prosessi kirjaimellisesti riistää oikeuden pitää hengissä sitä lasta ja lapsuutta, jota Jim on elänyt. Yrittäessään (turhaan) elvyttää henkiin japanilaista ystäväänsä, joka oli auttanut Jimiä fasaaniansojen yhteydessä, Jim kuvittelee itsensä lapseksi tämän paikalle. Samalla hän hokee hysteerisesti: "Pystyn herättämään kaikki henkiin!" Sodan vankileirikoulu on sellaisen kasvatusjärjestelmän kiteytymä, joka edesauttaa vieraantumista lapsuudesta, sen pyyhkimistä kokonaan pois. Tältä kannalta sota kontekstina on kasvatusprosessi, jossa pojat kasvavat miehiksi naisten ja lasten kustannuksella.

Myös kasvatusprosessina sota on kuitenkin paradoksaalinen ilmiö. Samalla kun se esittäytyy muutostilana, se tarjoaa laajemmassa aikaulottuvuudessa maaperän miehisen nostalgian pyrkimykselle kohti täydellistä, totaalista kokemusta. Voi jopa kärjistäen väittää, että yksilöpsykologisella tasolla sota on olemassa vain siksi, että se tarjoaa vieraantuneelle miehelle mahdollisuuden totaaliseen ja välittömään kokemukseen; sota on ikään kuin kontekstuaalinen tekosyy tuollaista kokemuksen kaipuuta varten. Tarjoaako valtiomies siis sodan sotamiehille ja elokuvantekijä elokuvan katsojille samassa tarkoituksessa?

Basie, Rawlins ja Nagata, kolmeen eri yhteiskuntajärjestelmään ja kansallisuuteen kuuluvat jäsenet yhdessä edustavat sitä maskuliinista Toista, jolla Jim yrittää “täyttää” itsessään olevat välttämättömät puutteet. Tässäkin suhteessa kasvu on tavallaan tyhjenemistä, sen oivaltamista, että mallit lopulta eivät täytä, vaan pikemminkin estävät. Sanoilla samoin kuin tavaroilla on kuitenkin oma funktionsa sekä suhteessa isä-hahmoihin että ympäröivään sodan todellisuuteen:

[Jim] piti Basien kopperosta. Esineiden runsaus, hyödyttömienkin, oli rauhoittavaa samalla tavoin kuin sanojen runsaus tohtori Ransomen lähistöllä. Latinan sanasto ja algebran termit olivat nekin hyödyttömiä, mutta ne auttoivat rakentamaan maailmaa (s. 213).

Todellisuuden pirstoutumisen hetkenä, kun amerikkalaisten lentokoneet hyökkäävät vankileiriin, Rawlins juoksee Jimin luo katolle ja yrittää tyynnytellä kiihtynyttä poikaa. Ympäristön äänet vaimenevat ja Jim toteaa: "En pysty muistamaan, miltä vanhempani näyttävät.” Tämän jälkeen hän alkaa mekaanisesti toistaa tohtorin "koulussa" oppimiaan latinankielen muotoja: "Amatus sum, amatus es, amatus est..." (minua on rakastettu, sinua on rakastettu, jne.) sekä "fugiendo vincimus" ("lentäen voitamme"). ${ }^{25}$ Oppimalla kieltä Jim on pyrkinyt säilyttämään etäisyyden suhteessa ympäristöönsä ja kokemuksiinsa. Kasvu on pakosta luopu- 
mista vanhasta minuudesta ja sen korvaamista annetuilla minä-kuvilla, "miehen malleilla", jotka pojan silmissä ovat välttämättä aina jotakin häntä itseään suurempaa. Tuota vanhaa edustaa Jimin lapsuuteen kuuluneita esineitä sisältänyt vanerinen matkalaukku. Elokuvan loppukuvassa tuo laukku kelluu yksinään likaisen veden pinnalla. Kirja puolestaan päättyy näin:

Arrawan keulan alla lipui lapsen arkku öiseen virtaan. Vanavesi huuhtoi irti sen paperikukat, kun yhteysvene toi merimiehiä amerikkalaiselta risteilijältä. Kukista muodostui arkun ympärille keinahteleva seppele, kun se aloitti pitkän matkansa Jangtsen suulle jolta tuleva vuoksi huuhtoisi sen vain takaisin jättömaan ja laitureiden keskelle, pakottaisi taas kerran tuon kauhean kaupungin rannoille (s. 336).

\section{Viitteet:}

1 Sven Hirn, Kuvat elävät. Elokuvatoimintaa Suomessa 19081918. Helsinki: VAPK-kustannus, Suomen elokuva-arkisto 1991, 207.

${ }^{2}$ Tästä perinteestä enemmän ks. Vance Kepley Jr., "Cinema and Everyday Life: Soviet Worker Clubs of the 1920s". Teoksessa Robert Sklar \& Charles Musser (eds.), Resisting Images; Essays on Cinema and History. Philadelphia: Temple University Press: 1990, 108-125.

${ }^{3}$ Ks. Lea Jacobsin artikkeli tässä julkaisussa.

${ }^{4}$ David Buckingham, "Teaching about the Media". Teoksessa David Lusted (ed.), The Media Studies Book. A guide for teachers. London, New York: Routledge 1991, 12-35.

${ }^{5}$ Ks. Henry Giroux \& Stanley Aronowitz, "The Politics of Clarity". Afterimage, (October 1991), 5.

${ }^{6}$ Ks. Manuel Alvarado, Robin Gutch, Tana Wollen, Learning the Media. An Introduction to Media Teaching. London: Macmillan 1987.

${ }^{7}$ Laajemmin tällaista vasta-asenteen problematiikkaa television kohdalla on käsitellyt Hannu Eerikäinen artikkelissaan "Broadcasting-järjestelmä, mediateknologian muutos ja vastatelevision utopia" (osa 1: Lähikuva 1/1992, 18-27 ja osa 2 tässä julkaisussa).

${ }^{8}$ Esim. David Morley, The 'Nationwide' Audience. London: BFI 1980.

${ }^{9}$ Len Masterman, Medioita oppimassa. Helsinki: KSL 1989 , 163-165.

${ }^{10}$ Tietysti tämänkin eron tekemisessä on syytä pitää mielessä ne huomiot, joita Persianlahden sodan ja median yhteyksistä on jo useallakin eri taholla esitetty - siis kysymys siitä, miten mediakin jo itsessään rinnastuu sodankäyntiin. Ks. esim. Margaret Morse, "Virtuaalinen sota: Persianlahden sota, televisio ja virtuaalitodellisuus". Lähikuva 2-3 (1991), 72-84.

${ }^{11}$ J. G. Ballard, Auringon valtakunta. Suom. Jussi Nousiainen. Otava: Keuruu 1988, 12. Jatkossa lainaukset tästä teoksesta on merkitty tekstin yhteyteen sulkeisiin lainauksen lopussa.

12 Tämäntyyppisistä vallan ja rahan yhteyksistä enemmän ks. luku "Valta ja kuva" teoksessa Jukka Sihvonen, Liekehtivät nalleverhot. Helsinki: LIKE 1987.

13 Tästä kehittelystä ks. lisää Slavoj Zizek, Looking Awry. An Introduction to Jacques Lacan through Popular Culture. Cambridge, Mass.: The MIT Press 1991, 29-30.

\section{${ }^{14}$ Ibid., 173, nootti 12 .}

15 Arnold van Gennep, The Rites of Passage. London: Routledge 1960; Victor Turner, The Ritual Process: Structure and AntiStructure. Chicago: Aldine Press 1969. Ks. myös Tuomo Turjan artikkelia tässä julkaisussa.

${ }^{16}$ Tällaista vallan kolmijakoa, joka pohjautuu Octave Mannonin ajatuksiin, on kehitellyt Slavoj Zizek teoksessaan For they know not what they do. Enjoyment as a Political Factor. London, New York: Verso 1991, 245-253.

17 Michael Ryan \& Douglas Kellner, Camera Politica. The Politics and Ideology of Contemporary Hollywood Film. Bloomington, Indianapolis: Indiana University Press 1988, 258-265.

18 Dennis Turner, "Made in U.S.A.: The American Child in Truffaut's 400 Blows". Film/Literature Quarterly. 12:2 (1984), 75-85.

19 Tania Modleski, "The Search for Tomorrow in Today's Soap Operas". Film Quarterly 33:1 (1979), 12-21.

${ }^{20}$ Paul Virilio, War and Cinema. The Logistics of Perception. London \& New York: Verso 1989 (alk. 1984), 11. Ilmailun ja elokuvan yhteyksistä Viriliolla on lukuisia muitakin esimerkkejä (D'Annunzio, Gance, jne.). Margaret Morse puolestaan viittaa Rudolf Arnheimin huomioimaan yhteyteen lentämisen ja television välillä; ks. M. Morse, "An Ontology of Everyday Distraction; The Freeway, the Mall, and Television" teoksessa Patricia Mellencamp (ed.), Logics of Television. Essays in Cultural Criticism. Bloomington: Indiana University Press 1990, 193.

${ }^{21}$ Sodan, elokuvan ja perhedraaman yhteyksistä ks. enemmän Tania Modleski, "A Father Is Being Beaten: Male Feminism and the War Film". Discourse X.2 (Spring-Summer 1988), 62-77. Modleskin mukaan sota tarjoaa miehelle "äärimmäisen auktoriteetin takaavan kokemuksen" (s. 67). Modleski soveltaa mm. Deleuzen näkemyksiä masokismin perusteista: poikalapsi lyöttäytyy äitinsä kanssa yhteen vastustamaan isän lakia, joka äidin on "pieksettävä" irti pojasta (kasvatus- ja kasvamisprosessi on sitten juuri tätä pieksämistä). Tästä syystä niin sotaan kuin ilmailuunkin liittyy niiden miehisyydestä riippumatta runsaasti feminiinistä (etenkin äitiä korostavaa) metaforiikkaa.

${ }^{22}$ Näistä lähtökohdista Deleuze esittelee ja tulkitsee Foucault'n valta-teorioita ja -tutkimuksia juuri erityyppisten käytänteiden historioina. Ks. Gilles Deleuze, Foucault. Minneapolis: University of Minnesota Press 1988 (alk. 1986), 70-93.

${ }^{23}$ Ibid., s. 83.

${ }^{24}$ Fantasian moniaineksisuuden juuret ovat Spielbergin lisäksi tietysti myös Ballardin tuotannossa. Vaikka Auringon valtakunta vasta nostikin kirjailijan laajemmin julkisuuteen, edeltää sitä lähes 20:nen tieteiskirjallisuuden piiriin kuuluvan novellikokoelman ja romaanin tuotanto, joka alkoi jo vuonna 1962 teoksella The Drowned World.

${ }^{25}$ Elokuvan videokopioon "fugiendo vincimus" on käännetty "lentäen voitamme", mutta itse asiassa fugio-verbi merkitsee perusmuodossaan "paeta, lähteä pakoon, karata, päästä pakoon, lähteä maanpakoon, rientää, kiitää pois, hälvetä, haihtua, kadota, hävitä, jne." Kirjaimellinen merkitys "pakenemalla voitamme" sopii Spielbergin käsittelytapaan kenties vieläkin täsmällisemmin kuin pelkkä "lentäminen", sillä viime kädessähän juuri siitä on kysymys: fantasian voitosta. Kiitän professori H.K. Riikosta avusta tämän huomion tulkinnassa. 